\title{
Service Time of JKN Outpatients in Selected Hospitals of Jakarta
}

\author{
Supriadi* \\ ${ }^{1}$ Hospital Administration Laboratory, Vocational Education Program, Universitas Indonesia \\ *E-mail: supriadi.vokasi@gmail.com
}

\begin{abstract}
One of the dimensions of patient satisfaction is patient waiting time, which is influenced by several factors, including patient registration service time. The reliability of the registration officer and the computer device used influence the timing of patient registration services. The reliability of the registration officer and the speed of the computer used help to increase the speed of patient registration service time. This study aims to measure the time duration of registration service, the reliability of officers, and the speed of the computer used from several hospitals. Five hospitals in Jakarta and their surroundings were used as the object of research. Patient registration service time as well as the reliability of registration officer and the speed of the computer used was measured by observation. The measurement results were compared with those of hospital $x$ that has already served JKN patients. The patient registration service time in five hospitals was 2-3 times longer than that in hospital $\mathrm{x}$. The reason is that the officers in these five hospitals were not able to provide patient registration and the computers used were slower than those of hospital x. These five hospitals should increase the speed of registration services to reduce patient waiting time, thereby increasing patient satisfaction.
\end{abstract}

Keywords: waiting time, service time

\section{Introduction}

National Health Insurance Program (JKN) is one of the programs organized by the Government of Indonesia that aims to improve health services as a whole, which was established by the Social Security Administering Board (BPJS) under Law (UU), that is, Law No. 40 of 2004 on the National Social Security System (SJSN) (Majid, 2014).

This JKN program has opened access to better health services to the community, leading to an increased number of visits to various health services, such as hospitals. This increase has resulted in an increased waiting time for patients to obtain health services (Bakis Firdaus \& Dewi, 2015).

Waiting time is one of the factors that determine patient satisfaction with the overall health service in the hospital. One aspect that affects the period of waiting time is the patient registration service at the registration counter (Bustani, Rattu, \& Saerang, 2015). Delay in admission or other chaotic processes display the overall impression of hospital services (Norton, Robertson, \& Anderson, 2010).

Patient admission at the registration counter is the first step in availing the services offered by a health care institution. This registration service may determine patients' impression on the overall service of the hospital as a whole. Thus, the administrator always identifies and improves the patient registration service process (Norton et al., 2010).

\section{Literature Review}

As healthcare providers, hospital staff must ensure quality, efficiency, and acceptable services to their customers. A patient is their most important customer. In a competitive environment, the patient's perception of quality healthcare is an important factor in choosing a hospital. Considering the rising standards of living and high expectations, healthcare services must provide a sustainably high standard for their customers (Bakan, Buyukbes, \& Ersahan, 2014).

Paying attention to patient-centered actions and outcomes has become increasingly important. Focus on patient preferences and needs ensuring that patient values are considered in all the decision-making processes to improve patient satisfaction (Heidegger, Saal, \& Nubling, 2013). 
To identify the quality of services, we can use some satisfaction indicators, such as service quality (SERVQUAL), which includes five dimensions, namely, tangibles, reliability, responsiveness, assurance, and empathy (Parasuratman, 1988; Novianti \& Artanti, 2015; Styaningsih, 2013).

Patient waiting time is one of the potential components causing dissatisfaction. Length of the waiting time reflects how a hospital manages the service components tailored to the situation and expectations of a patient (Bakis Firdaus, 2015).

Moreover, the patient registration service time is strongly influenced by reliability and responsiveness of the officers, aided by supporting equipment and an efficient system. A rapid service time reduces the number of queues and shortens the patient waiting time, indicating as a component of patient satisfaction (Bakis Firdaus, 2015; Parasuratman, 1988; Novianti et al., 2015).

\section{Methodology}

This study aims to determine the speed of service on the outpatient registration of JKN and the factors influencing this speed. It uses a qualitative approach. The data consisted of the observation of service time from the moment the patient was called at the registration counter until the completion of transaction at the counter. Ten patients participated for the observation. The dexterity of officers, the number of officers, the speed of the computer, and the average number of patients per day were also observed. To avoid considerably different results, we incorporated five hospitals in this study, with the assumption of having the same policies, procedures, and standards. We then compared the five hospitals with another hospital (hospital $\mathrm{x}$ ) that had previously served JKN patients and had experienced serving patients with universal assurance with service time.

Patient waiting time was previously researched by Bustani et al. (2015) and Torry, Koeswo, and Sujianto (2016), wherein they calculated the waiting time from the time the patients arrived until they finished acquiring the drug. Norton et al. (2010) calculated the waiting time and identified the determinants of service quality on patient registration.

\section{Results and Discussion}

The results of service time observation in patient registration, the number of service personnel, and the average number of patients per day in the five hospitals and hospital $\mathrm{x}$ are as follows:

Table 1 Service Time in the Registration Admission of Six Hospitals

\begin{tabular}{|c|c|c|c|c|}
\hline Hospital & $\begin{array}{c}\text { Average service } \\
\text { time }\end{array}$ & $\begin{array}{c}\text { Number } \\
\text { of } \\
\text { officer }\end{array}$ & $\begin{array}{l}\text { Average } \\
\text { no. of } \\
\text { patients } \\
\text { per day }\end{array}$ & $\begin{array}{l}\text { Assumption of } \\
\text { time served in all } \\
\text { patients }\end{array}$ \\
\hline RS 1 & $\begin{array}{l}3 \text { minutes, } 18 \\
\text { seconds }\end{array}$ & 3 & 333 & $\begin{array}{c}6 \text { hours, } 6 \\
\text { minutes }\end{array}$ \\
\hline RS 2 & $\begin{array}{c}2 \text { minutes, } 9 \\
\text { seconds }\end{array}$ & 3 & 447 & $\begin{array}{c}5 \text { hours, } 20 \\
\text { minutes }\end{array}$ \\
\hline RS 3 & $\begin{array}{c}3 \text { minutes, } 8 \\
\text { seconds }\end{array}$ & 3 & 320 & $\begin{array}{c}5 \text { hours, } 34 \\
\text { minutes }\end{array}$ \\
\hline RS 4 & $\begin{array}{c}3 \text { minutes, } 3 \\
\text { seconds }\end{array}$ & 3 & 376 & $\begin{array}{c}6 \text { hours, } 32 \\
\text { minutes }\end{array}$ \\
\hline RS 5 & $\begin{array}{c}3 \text { minutes, } 4 \\
\text { seconds }\end{array}$ & 2 & 230 & $\begin{array}{c}6 \text { hours, } 53 \\
\text { minutes }\end{array}$ \\
\hline $\mathrm{RS} x$ & 45 seconds & 3 & 378 & $\begin{array}{c}1 \text { hours, } 56 \\
\text { minutes }\end{array}$ \\
\hline
\end{tabular}

As shown in Table 1, the average service time for patients in the first five hospitals ranged from 2 minutes and 9 seconds to 3 minutes and 18 seconds. Furthermore, the length of service time between one hospital and another was not considerably different, possibly because the five hospitals have the same policies, procedures, and service standards. However, hospital x obtained extremely different results from those of the five hospitals; the average patient registration service time for hospital $x$ was only 45 seconds. This service time is considerably shorter than that of the five hospitals. In the studies of Bustani et al., at one of the branches of Eye Health Centers of the Community in North Sulawesi, the service registration time was within 2-7 minutes, whereas the total waiting time was within 100-200 minutes. Torry et al. (2016) showed an average patient registration time of 8 minutes and 56 seconds. Moreover, Norton et al. (2010) obtained a patient acceptance 
service time of 15-30 minutes; the time of registration service in this research included the activity of patients in relation to their health history.

Along with the average service time, the number of officers, and the average number of patients per day in five hospitals, the time required to serve all patients ranged from 5 hours and 20 minutes to 6 hours and 53 minutes, whereas that in hospital $\mathrm{x}$ was only 1 hour and 56 minutes. Therefore, the time required in these hospitals was 2-3 times longer than that in hospital $\mathrm{x}$. The average amount of service time and the number of officers greatly affected the service time of all patients. Thus, patient waiting time should be shortened (Bustani, et al., 2015).

The time of patient registration service is influenced by several factors, such as officer agility, completeness of the collected data, computer ability, and internet connection (Bustani et al., 2015; Norton et al., 2010; Torry et al., 2016). Observations showed that the individual registration officers of the five hospitals were not as capable as the one in hospital x. Furthermore, the computer equipment and connection speed at the registration service of the five hospitals were not as fast as those in hospital $\mathrm{x}$, thereby further affecting the service time.

As previously mentioned, one indicator of hospital satisfaction is patient waiting time. Rapid registration service reduces patient waiting time, causing an impact to the quality of service and improvement in patient satisfaction (Majid, 2014; Besta, 2018; Hazfiarini \& Ernawaty, 2016). Regarding the dimensions of reliability and responsiveness in SERVQUAL, reliable officers who can perform services quickly and are agile will aid in the increase of patient satisfaction (Parasuratman, 1988; Torry et al., 2016; Rumengan, Umboh, \& Kandou, 2015).

\section{Conclusion}

The service time during registration is influenced by several factors, such as the reliability of the officer and the computer equipment used. Short registration time reduces patient waiting time in obtaining health services, and short waiting time is one of the dimensions of patient satisfaction.

The five hospitals with similar characteristics in this study can still increase the speed of registration services by increasing the reliability and speed of officers in serving the patient registration, in addition to upgrading the computer used by the registration officer. Consequently, the outpatient registration service will be shortened and directly increase patient satisfaction.

\section{Acknowledgments}

Thank to the Laboratory of Hospital Administration Program for assistance in conducting observations in six hospitals as research objects. Thanks also to the Vocational Research Unit which has helped provide input in the preparation of this paper. Special thanks to the Director of Vocational Education Program of University of Indonesia who has provided direction in the preparation of this paper. Hopefully the results of this study can be a reference for further research.

\section{References}

Bakan, I., Buyukbese, T., \& Ersahan, B. (2014). The impact of total quality service (TQS) on healthcare and patient satisfaction: An empirical study of Turkish private and public hospital. The International Journal of Health Planning Management, 29(3), 292-315.

Bakis Firdaus, FF, \& Dewi, A. (2015). Evaluation of service quality towards outpatient BPJS participants satisfaction in Panembahan Senopati Bantul Distrik Hospital. Jurnal Medicoeticolegal dan Manajemen Rumah Sakit, 4(2).

Besta, V. M. (2018). Studi pelayanan publik: Peserta Badan Penyelenggara Jaminan Sosial (BPJS) Kesehatan di Ruma Sakit Umum Daerah (RSUD) Teluk Kuantan Kabupaten Kuantan Singingi Tahun 2016. JOM FISIP. 5(1).

Bustani, N. M., Rattu, A. J., \& Saerang, J. S. M. (2015). Analisis lama waktu tunggu pelayanan pasien rawat jalan di balai kesehatan mata masyarakat Propinsi Sulawesi Utara. Jurnal e- Biomedik, 3(3).

Hazfiarini, A., \& Ernawaty, E. (2016). Satisfaction index of BPJS Kesehatan patient toward community Eye Hospital East Java Service. Jurnal Administrasi Kesehatan Indonesia, 4(2), 77-85.

Heidegger, T., Saal, D., \& Nubling, M. (2013). Patient satisfaction with anasthesia-Part 1:Satisfaction as part of outcomeand what satisfies patient. Anaesthesia, 68(11), 1165-1172.

Majid, F. A. N. (2014). Analysis description of outpatient journey at RS Kanker "Dharmais" in 2014. Jurnal Administrasi Rumah Sakit Indonesia, 1(1).

Norton, D., Robertson, S., \& Anderson, R. (2010). A randomized controlled trial to assess the impact of an Admission Service on patient and staff satisfaction. International Journal of Nursing Practice, 16(5), 461-471.

Novianti, R., \& Artanti, Y. (2015). Pengaruh kualitas layanan terhadap word of mouth (WOM) melalui kepuasan sebagai variabel intervening. Jurnal Ilmu Manajemen, 3(1). 
Parasuratman, A. (1988). SERVQUAL: A multi item scale for measuring consumer perceptions of quality. Journal of Retailing, 12-38

Rumengan, D. S. S., Umboh, J. M. L., \& Kandou, G. D. (2015). Factor associated with health care utilization health on BPJS participants in PHC Paniki Mapanget Down District of Manado. JIKMU, Suplemen 5(1).

Styaningsih, I. (2013). Analisis kualitas pelayanan rumah sakit terhadap pasien mengunakan pendekatan LEAN SERVPERF (Lean Service dan Service Performance). Spektrum Industri, 11(2), 117-242.

Torry, Koeswo M, \& Sujianto. (2016). Factor influencing service waiting time in relation to internist clinik outpatient's satisfaction at Dr Iskak Public Hospital Tulungagung. Jurnal Kedokteran Brawijaya, 29(3). 